\title{
Avoidance Coping dan Kebermaknaan Hidup pada Lansia di Panti Werdha
}

\author{
Mochammad Sa'id*1. Djudiyah \\ *Fakultas Pendidikan Psikologi Universitas Negeri Malang \\ Fakultas Psikologi Universitas Muhammadiyah Malang \\ email:djudiyahdahlan2@gmail.com, mochammad.sa'id.fppsi@um.ac.id
}

\begin{abstract}
Artikel INFO
Diterima:25 Januari 2019

Direvisi :16 April 2019

Disetujui: 29 April 2019

DOI:

http://dx.doi.org/10.24014/ jp.v14i2.6655

Kehidupan yang dijalani para lansia di panti werdha tentu berbeda dengan kehidupan yang mereka jalani bersama keluarga di rumah. Hal ini menuntut kemampuan coping yang memadai. Kemampuan dalam strategi coping sangat erat kaitannya dengan kemampuan untuk menemukan makna hidup dan mencapai kehidupan yang bermakna. Penelitian ini bertujuan untuk mengetahui hubungan antara strategi avoidance coping dan kebermaknaan hidup pada lansia yang tinggal di panti werdha. Pengambilan data penelitian dilakukan dengan menyebarkan skala avoidance coping dan skala kebermaknaan hidup pada 25 lansia yang tinggal di Panti Werdha Mojopahit Kabupaten Mojokerto Jawa Timur. Para lansia yang dipilih sebagai responden penelitian ini ditentukan dengan teknik purposive sampling. Hasil analisis menunjukkan bahwa avoidance coping tidak memiliki hubungan yang signifikan dengan kebermaknaan hidup pada para lansia di panti werdha. Hasil penelitian ini merekomendasikan, bagi penelitian selanjutnya, untuk melakukan pengumpulan data dalam jumlah sampel yang lebih besar dengan teknik random sampling. Hal ini diharapkan dapat meningkatkan generalisasi hasil penelitian sehingga lebih representatif.
\end{abstract}

\section{Abstrak}

Kata Kunci: avoidance coping, kebermaknaan hidup, lansia, panti werdha

\section{Avoidance Coping and Meaningfulness of Life in the Elderly at the Nursing Home}

\begin{abstract}
The life of the elderly in nursing homes is certainly different from the life they live with family at home. This requires adequate coping skills. The ability in coping strategies is very closely related to the ability to find meaning in life and achieve meaningful life. The aim of this study is to determine the relationship between avoidance coping strategies and the meaningfulness of life in the elderly who live in nursing homes. Research data were gathered by spreading avoidance coping scale and meaningful life scale in 25 elderly people who lived in Panti Werdha Mojopahit, Mojokerto Regency, East Java. The elderly chosen as respondents of this study were determined by purposive sampling technique. The results of the analysis show that avoidance coping does not have significant relationship with meaningfulness of life in the elderly in nursing homes. The results of this study recommend, for further research, to collect data in a larger number of samples with random sampling techniques. This is expected to increase the generalization of the results of the study so that it is more representative.
\end{abstract}

Keywords: avoidance coping, meaningfulness of life, the elderly, nursing home

\section{Pendahuluan}

Jumlah penduduk lansia (lanjut usia) di Indonesia, dengan batasan usia 60 tahun ke atas, menunjukkan tren peningkatan dari tahun ke tahun. Siti Setiati (Kompas, 2017a) mengemukakan bahwa Indonesia saat ini menjadi negara dengan penduduk yang menua, di mana 1 dari 10 penduduk Indonesia berusia lanjut. Data sensus penduduk memaparkan fakta bahwa penduduk lansia Indonesia tahun 2010 berjumlah 18,1 juta jiwa (7,6 persen dari total populasi), kemudian 
meningkat pada 2014 menjadi 20,24 juta jiwa (8,03 persen dari total populasi), dan semakin meningkat menjadi 22,6 juta jiwa pada 2016. Jumlah mereka diperkirakan akan mencapai 41 juta jiwa pada 2030, sehingga Indonesia dapat dikatakan akan memiliki populasi menua (aging population) (Kompas, 2017b).

Kenyataan di atas membutuhkan perhatian serius, terutama terkait dengan pemenuhan kebutuhan para lansia, baik kebutuhan fisik, psikologis, maupun sosial. Masa lansia merupakan masa yang ditandai dengan perubahan baik secara fisik, kognitif, maupun sosio-emosional. Dalam kenyataan di masyarakat, perubahan-perubahan tersebut membuat banyak keluarga memilih untuk menempatkan para lansia di panti werdha. Ada beberapa alasan yang seringkali dikemukakan, mulai dari ketidakmampuan secara ekonomi, kurangnya fasilitas, hingga kesulitan untuk merawat para lansia akibat kesibukan kerja (Windy, 2017). Dengan alasan-alasan tersebut, mereka berharap bahwa dengan tinggal di panti werdha para lansia akan mendapatkan perawatan yang lebih baik.

Lingkungan fisik dan sosial panti werdha sangatlah berbeda dengan lingkungan rumah. Perubahan lingkungan fisik dan sosial yang dialami para lansia ini seringkali menimbulkan stres (Santrock, 2002). Beberapa pertanyaan yang muncul di antara lansia adalah mengenai kemampuan untuk menyesuaikan diri dan kebebasan. Dalam menjalani kehidupan di panti werdha, mereka memang dituntut untuk mampu beradaptasi dengan kelompok sosial barunya (Puspitaningsih, 2015).

Kehidupan baru di panti werdha juga menuntut kemampuan para lansia dalam penyelesaian masalah atau yang disebut dengan strategi coping. Coping adalah strategi yang digunakan oleh individu dalam menghadapi berbagai peristiwa ataupun situasi yang dapat menimbulkan stres. Strategi ini dapat berupa perubahan cara berpikir (kognitif) maupun dengan melakukan tindakan tertentu (Lazarus \& Folkman, 1984).

Moos (Chinaveh, 2012) membagi strategi coping menjadi dua jenis. Pertama, strategi mendekati (approach coping). Strategi ini meliputi upaya kognitif dan perilaku untuk mengatasi atau menyelesaikan stresor kehidupan. Strategi ini mengarah pada problem-focused coping sebagaimana yang dikemukakan oleh Lazarus \& Folkman (1984). Kedua, strategi menghindar (avoidance coping). Strategi ini dicirikan dengan penggunaan cara kognitif dan perilaku untuk menghindar dari berpikiran tentang stresor dan dampaknya, atau dengan mengelola perasaan dan emosi yang berkaitan dengan stresor. Strategi ini mengarah pada emotion-focused coping sebagaimana yang dikemukakan oleh Lazarus \& Folkman (1984). Setiap individu memiliki strategi coping yang sangat mungkin berbeda dengan individu lainnya, tergantung pada kepribadian dan tingkat stres dari kondisi ataupun masalah yang dialaminya.

Kemampuan coping akan sangat menentukan kemampuan penyesuaian diri para lansia dalam menjalani kehidupan di panti werdha (Santrock, 2002). Penelitian Rodin dan Langer (Santrock, 2002) juga membuktikan bahwa pemberian pilihan untuk kontrol dan penentuan diri serta mengajarkan keterampilan coping sangat berpengaruh terhadap kesehatan dan kesejahteraan psikologis lansia.

Kemampuan dan pemilihan jenis strategi coping juga sangat berkaitan dengan kebermaknaan hidup (Park \& Folkman, 1997). Frankl (2003) mendefinisikan makna hidup sebagai sesuatu yang unik dan khusus yang harus dimiliki oleh seseorang, dan hanya dengan cara itulah manusia akan memiliki arti dalam hidupnya. Menurut Frankl, keinginan dan pencarian terhadap makna merupakan kekuatan utama yang harus dimiliki oleh setiap manusia dalam hidupnya, bukan sekedar rasionalisasi dari insting-insting perilaku.

Makna hidup merupakan sesuatu yang dianggap dan dirasakan penting, benar, berharga dan didambakan, serta memberikan nilai khusus bagi seseorang dan layak dijadikan tujuan hidup. Apabila makna hidup ini telah ditemukan, maka kehidupan orang tersebut akan berarti, sehingga yang bersangkutan dapat merasakan kebahagiaan dan terhindar dari rasa putus asa (Bastaman, 2007). 
Individu yang mampu menemukan makna hidup dalam aktivitas yang dilakukannya akan memiliki tujuan hidup (life purpose), existential vacuum, hidupnya lebih terkontrol (life control), menerima kematian (death acceptance), selalu berusaha mencari dan menemukan makna (will to meaning), mencari tujuan-tujuan baru (goal seeking), mampu menemukan makna untuk aktivitas yang akan datang (future meaning) (Reker, Peacock, \& Wong, 1987). Dengan demikian, lansia yang memiliki makna hidup akan menjalani hidupnya dengan nyaman dan bahagia. Mereka memiliki persepsi positif terhadap tingkat kesehatan pribadi mereka, tidak banyak mengalami kecemasan dan gangguan tidur, lebih fungsional secara sosial, dan lebih sehat secara psikologis. Oleh karena itu, makna hidup secara signifikan berhubungan dengan kesehatan psikologis umum pada lansia (Kleftaras \& Pserra, 2012).

Lansia yang menggunakan strategi coping dengan adaptif atau approach coping mampu menemukan makna dalam mengatasi problem psikososial yang dialaminya (Langer, 2004; Singh \&Mahato, 2014). Merekaberusaha menjalankan sholat, berdo'a, membaca bukubuku agama, mengunjungi tempat-tempat wisata religi, dan sebagainya. Dengan cara demikian, mereka merasa lebih bahagia dan sehat secara fisik maupun psikologis. Sebaliknya, lansia yang menggunakan startegi coping yang negatif atau avoidance coping (seperti minum alkohol, melupakan masalah atau tidak mau berpikir tentang persoalan yang dialami) merasa cemas, sedih, dan tidak berdaya dalam mengatasi problem psikososial yang dialaminya. Hal ini senada dengan hasil penelitian yang dilakukan baik oleh Stanton dkk. maupun Nolen-Hoeksema dkk. (Folkman \& Moskowitz, 2004). Meski demikian, penelitian lain yang dilakukan oleh Yuliana (2018) menunjukkan hasil yang berbeda. Dalam penelitian tersebut, strategi coping tidak memiliki hubungan yang signifikan dengan makna hidup.

Studi Puspitaningsih (2015) di Panti Werdha Mojopahit Kabupaten Mojokerto menunjukkan bahwa sebagian dari para lansia yang tinggal di dalamnya merasa belum puas dengan kondisi barunya. Mereka belum bisa menjalani kehidupan secara lebih mandiri di panti dan bersosialisasi dengan penghuni panti lainnya. Sedangkan sebagian lainnya merasa puas dengan kehidupan baru mereka di panti, mampu lebih mandiri, dan bahkan berusaha saling menolong dan menghibur sesama penghuni panti.

Berangkat dari pemaparan di atas, penelitian ini dilakukan dengan tujuan untuk mengetahui hubungan antara strategi avoidance coping dan kebermaknaan hidup para lansia yang tinggal di Panti Werdha Mojopahit Kabupaten Mojokerto.

\section{Metode}

Penelitian ini merupakan penelitian korelasional. Responden penelitian ini adalah para lansia yang tinggal di Panti Werdha Majapahit Kabupaten Mojokerto. Jumlah responden penelitian ini adalah 25 lansia dari 41 lansia yang tinggal di panti. Responden penelitian ini terdiri dari 4 laki-laki dan 21 perempuan. Metode pengambilan sampel yang digunakan adalah purposive sampling. Para lansia yang dipilih sebagai responden penelitian ini didasarkan pada kriteria-kriteria berikut ini:

1. Berusia 61 tahun ke atas

2. Telah dan sedang tinggal di Panti Werdha Mojopahit minimal 6 bulan

3. Bersedia menjadi responden penelitian

Variabel bebas pada penelitian ini adalah avoidance coping dan variabel tergantungnya adalah kebermaknaan hidup. Avoidance coping merupakan upaya untuk menerima dan menghadapi stressor kehidupan dengan mencari alternatif reward dengan melepaskan emosi. Avoidance coping terdiri dari dua dimensi, yaitu aspek kognitif dan perilaku. Sedangkan kebermaknaan hidup merupakan kemampuanindividu untukmenemukanmakna dari aktivitas sehari-hari yang dialaminya baik yang bersifat positif maupun negatif. Makna hidup memiliki tiga aspek, yaitu, unik, nyata dan spesifik, memberi pedoman dan arah. 


\section{Pengukuran}

Pengumpulan data dalam penelitian ini dilakukan dengan menggunakan dua skala, yaitu skala strategi coping menghindar (avoidance coping) dan skala kebermaknaan hidup. Skala strategi coping menghindar (avoidance coping) yang digunakan dalam penelitian ini diadaptasi dari skala yang dikembangkan oleh Chinaveh berdasarkan teori yang dikemukakan oleh Moos (Chinaveh, 2012). Sedangkan skala kebermaknaan hidup yang digunakan dalam penelitian ini diadaptasi dari skala kebermaknaan hidup yang dikembangkan oleh Ritaudin (2013). Kedua skala tersebut menggunakan model Likert dengan 5 alternatif jawaban, yaitu: SS (Sangat Sesuai), S (Sesuai), CS (Cukup Sesuai), TS (Tidak Sesuai) dan STS (Sangat Tidak Sesuai).

Skala strategi coping menghindar (avoidance coping) terdiri dari 15 item dengan reliabilitas 0.88 cronbach alpha. Sedangkan skala kebermaknaan hidup terdiri dari 20 item dengan koefisien reliabilitas 0.92 cronbach alpha.

\section{Teknik Analisis Data}

Analisis data dalam penelitian ini menggunakan teknik analisis korelasi (Gravetter \& Wallnau, 2009) untuk melihat hubungan antara strategi coping menghindar (avoidance coping) dan kebermaknaan hidup pada para responden penelitian.

\section{Hasil}

Hasil statistik deskriptif dapat dilihat pada Tabel 1. Sedangkan hasil kategorisasi avoidance coping dan kebermaknaan hidup para lansia dapat dilihat pada Tabel 2.

Tabel 1. Deskripsi data empirik dan hipotetik penelitian

Data Empirik

\begin{tabular}{lccccc}
\hline Variabel & N & Mean & SD & Min & Max \\
\hline $\begin{array}{l}\text { Avoidance } \\
\text { Coping }\end{array}$ & 25 & 37,04 & 2,951 & 28 & 42 \\
$\begin{array}{l}\text { Kebermaknaan } \\
\text { Hidup }\end{array}$ & 25 & 59,92 & 7,365 & 42 & 79 \\
\hline $\begin{array}{l}\text { Data Hipotetik } \\
\text { Variabel }\end{array}$ & N & Mean & SD & Min & Max \\
\hline
\end{tabular}

\begin{tabular}{llllll}
\hline $\begin{array}{l}\text { Avoidance } \\
\begin{array}{l}\text { Coping } \\
\text { Kebermaknaan }\end{array}\end{array}$ & 25 & 45 & 5 & 15 & 75 \\
\begin{tabular}{l} 
Hidup \\
\hline
\end{tabular} & 25 & 60 & 5 & 20 & 100 \\
\hline
\end{tabular}

Tabel 2. Kategorisasi variabel penelitian

\begin{tabular}{|llll|}
\hline \multicolumn{4}{l}{ Kategorisasi } \\
\hline Norma & Kategori & Frekuensi & $\%$ \\
\hline $50 \leq X$ & Tinggi & 0 & 0 \\
\hline $40 \leq X<50$ & Sedang & 5 & 20 \\
\hline$X<40$ & Rendah & 20 & 80 \\
\hline Kategorisasi Kebermaknaan Hidup & \\
\hline Norma & Kategori & Frekuensi & $\%$ \\
\hline $65 \leq X$ & Tinggi & 5 & 20 \\
\hline $55 \leq X<65$ & Sedang & 17 & 68 \\
\hline$X<55$ & Rendah & 3 & 12 \\
\hline
\end{tabular}

Hasil penelitian ini menunjukkan bahwa tingkat avoidance coping para lansia panti werdha yang menjadi responden penelitian termasuk kategori rendah. Kategori ini sejalan dengan skor mean empirik yang lebih rendah dibandingkan dengan skor mean hipotetiknya. Hasil ini berbeda dengan temuan Singh dan Mahato (2014) bahwa lansia yang tinggal di panti asuhan cenderung menggunakan coping negatif dalam menghadapi problem psikososial yang dihadapinya.

Tingkat kebermaknaan hidup para responden termasuk kategori sedang. Meskipun demikian, skor mean empirik lebih rendah dibandingkan dengan skor mean hipotetik, sehingga dapat disimpulkan bahwa rata-rata kebermaknaan hidup responden sebenarnya rendah.

Hasil uji hipotesis yang dilakukan dengan teknik korelasi product moment menunjukkan nilai korelasi $-0,113$ dengan sign. 0,591 > 0,05 . Hal ini membuktikan bahwa tidak ada hubungan yang signifikan antara avoidance coping dengan kebermaknaan hidup pada lansia di Panti Werdha Mojopahit di Kabupaten Mojokerto.

\section{Pembahasan}

Hasil uji hipotesis penelitian ini menunjukkan bahwa tidak ada hubungan 
yang signifikan antara avoidance coping dan kebermaknaan hidup pada lansia di Panti Werdha Mojopahit yang dikelola oleh Pemerintah Daerah Kabupaten Mojokerto. Hasil ini senada dengan penelitian yang dilakukan oleh Yuliana (2018). Dalam penelitian tersebut, pilihan strategi coping tidak memiliki hubungan yang signifikan dengan makna hidup.

Hubungan yang tidak signifikan di antara kedua variabel di atas kemungkinan muncul karena beberapa sebab. Pertama, mereka tampaknya belum mampu menemukan makna hidup untuk dijadikan sebagai tujuan hidup mereka (IImi dkk., 2018). Kemungkinan penyebabnya adalah karena keberadaan mereka di panti werdha bukan didorong oleh keinginan sendiri, tetapi karena keterpaksaan, seperti ketidakmampuan secara ekonomi, kurangnya fasilitas, dan kesulitan untuk merawat para lansia akibat kesibukan kerja (Windy, 2017).

Kebermaknaan hidup, sebagaimana dikemukakan oleh Frankl (2003), adalah kemampuan seseorang untuk menemukan makna dalam hidupnya dan menjadikannya sebagai tujuan hidup. Ketika hal itu terjadi, maka lansia akan mencapai kebahagiaan dan bebas dari rasa putus asa, bahkan ketika lansia sedang berada dalam kondisi penderitaan sekalipun. Oleh karena itu, orangorang yang mampu menemukan makna dalam hidupnya akan mampu bertahan dan terus berjuang dalam menghadapi kondisi hidupnya, bagaimanapun keadaannya, demi mencapai makna hidup yang dimiliki.

Kehidupan para lansia yang tinggal di panti werdha ini memang lebih terjamin, baik dari sisi pangan, sandang, maupun papan (physiological needs). Dengan demikian mereka menjadi lebih sejahtera dan bahagia hidupnya dibanding sebelum masuk ke panti werdha ini. Hal ini senada dengan apa yang dikemukakan oleh Feldman (2000) bahwa pemenuhan kebutuhan-kebutuhan hidup sangatlah penting bagi pencapaian kesejahteraan psikologisnya, yang ia istilahkan sebagai keadaan homeostasis (keseimbangan). Meskipun demikian, sebagaimana pendapat Maslow (Koltko-
Rivera, 2006), pemenuhan kebutuhan yang sifatnya material dan fisiologis belum tentu meningkatkan kebermaknaan hidup seseorang. Hal ini dikarenakan tujuan hidup seseorang bukanlah hanya sesuatu yang bersifat material dan fisiologis.

Kedua, strategi coping adalah cara yang digunakan dan dipilih oleh individu dalam menghadapi berbagai peristiwa ataupun situasi yang dapat menimbulkan stres. Setiap individu memiliki strategi coping yang sangat mungkin berbeda dengan individu lainnya, tergantung pada kepribadian dan tingkat stres dari kondisi ataupun masalah yang dialami dan dirasakannya (Lazarus \& Folkman, 1984; Allen \& Leary, 2010). Dalam konteks penelitian ini, pilihan strategi coping para responden kemungkinan lebih berkaitan dengan hal-hal lain, seperti kepribadian dan tingkat stres dari permasalahan atau kondisi yang mereka alami dan rasakan selama tinggal di panti werdha. Kehidupan di panti werdha sangat berbeda dengan kehidupan yang dialami para responden di rumah. Meskipun demikian, kehidupan mereka setidaknya lebih terjamin. $\mathrm{Hal}$ inilah yang dapat menjelaskan bahwa meskipun kebermaknaan hidup responden dalam penelitian ini berada dalam kategori sedang, namun avoidance coping mereka berada dalam kategori rendah.

Para lansia yang tinggal di panti werdha merupakan orang-orang yang memiliki keterbatasan fisik dan komunikasi. Untuk dapat melakukan proses pengumpulan data secara memadai, para lansia yang dipilih sebagai sampel penelitian ini adalah mereka yang masih mampu berkomunikasi dengan baik dan memungkinkan untuk mengisi instrumen penelitian. Selain itu, penelitian ini juga dilaksanakan hanya di salah satu panti werdha, yaitu Panti Werdha Mojopahit Kabupaten Mojokerto. Hal itu mempengaruhi penentuan teknik sampling yang dipilih, yaitu purposive sampling, yang pada akhirnya berdampak pada kecilnya jumlah responden yang menjadi sampel penelitian ini.

\section{Kesimpulan}

Penelitian ini bertujuan untuk mengetahui hubungan antara avoidance 
coping dan kebermaknaan hidup pada lansia yang tinggal di panti werdha. Hasil penelitian ini menunjukkan bahwa tidak terdapat hubungan yang signifikan antara avoidance coping dengan kebermaknaan hidup pada lansia yang tinggal di Panti Werdha Mojopahit Kabupaten Mojokerto Jawa Timur.

Hasil penelitian ini merekomendasikan, bagi penelitian selanjutnya, mengenai pentingnya pengumpulan data penelitian dalam jumlah sampel yang lebih besar dengan teknik random sampling. Hal ini diharapkan dapat meningkatkan generalisasi hasil penelitian sehingga lebih representatif.

\section{Daftar Pustaka}

Allen, A., \& Leary, M. (2010). Self-compassion, stress, and coping. Social and Personality Psychology Compass, 4 (2), 107-118.

Barusch, A. S. (1988). Problems and coping strategies of elderly spouse caregivers. The Gerontologist, 28(5), 677-685. doi:10.1093/geront/28.5.677

Bastaman, H. (2007). Logoterapi: Psikologi Untuk Menemukan Makna Hidup Dan Meraih Hidup Bermakna. Jakarta: PT Raja Grafindo Persada.

Chinaveh, M. (2012). The examination of reliability and validity of coping responses inventory among Iranian students. 3rd World Conference on Psychology, Counselling, and Guidance (pp. 607-6014). Amsterdam: Elsevier.

Feldman, R. S. (2000). Understanding Psychology. Singapore: McGraw-Hill College.

Folkman, S., \& Moskowitz, J. T. (2004). Coping: Pitfalls and promise. Annual Review of Psychology, 55(1), 745-774. doi:10.1146/annurev. psych.55.090902.141

Frankl, V. (2003). Logoterapi: Terapi Psikologi Melalui Pemaknaan Eksistensi. (M. Murtadlo, Terj.). Yogyakarta: Kreasi Wacana.

Gravetter, F. J., \& Wallnau, L. B. (2009). Statistic for The Behavioral Sciences. Singapore: Wadsworth, Cengage Learning.
IImi, N., Masri, M., Wardiman, Hamid, S.N.A., Adama, W., Sutria, E., Muaningsih, \& Patima. (2018). Problem depresi lansia dan solusi dengan terapi spritual (Literature review: Problem of depression of erderly and the solution with spiritual therapy). Journal of Islamic Nursing, 3 (1), 32-39.

Kleftaras, G. \& Pserra, E. (2012). Meaning in life, psychological well-being, and depressive symptomatology: a comparative study. Psychology, 3 (4), 337-345. http://dx.doi.org/10.4236/ psych.2012.34048

Koltko-Rivera, M.E. (2006). Rediscovering the later version of Maslow's hierarchy of needs: Self-transcendence and opportunities for theory, research, and unification. Review of General Psychology, 10 (4), 302-317. doi: 10.1037/1089-2680.10.4.302

Kompas. (2017a, 23 Februari). Diakses 11 Maret 2018, dari Kompas: https://lifestyle.kompas.com/ read/2017/02/23/140000623/ penduduk.ri.menuju.menua.

Kompas. (2017b, 20 Mei). Diakses 11 Maret 2018, dari Pressreader: https:// www.pressreader.com/indonesia/ kompas/20170520/281831463668837

Langer, N. (2004). Resiliency and spirituality: foundations of strengths perspective counseling with the elderly. Educational Gerontology, 30(7), 611-617. doi:10.1080/03601270490467038

Lazarus, R., \& Folkman, S. (1984). Stress, Appraisal, and Coping. New York: Springer.

Park, C. L., \& Folkman, S. (1997). Meaning in the context of stress and coping. Review of General Psychology, 1(2), 115-144. doi:10.1037/1089-2680.1.2.115

Puspitaningsih, D. (2015). Adaptasi diri pada lansia di panti werdha Mojopahit Mojokerto. Hospital Mojopahit, 6 (2), 40-50.

Reker, G.T., Peacock, E.J., \& Wong, P.T.P. (1987). Meaning and purpose in life and well-being: A life-span perspective. Journal of Gerontology, 42(1), 44-49. 
DOI: $10.1093 /$ geronj/42.1.44

Ritaudin, A. (2013). Hubungan Kebermaknaan Hidup dengan Kinerja Anggota Dinar Vision Club (DVC) di Perusahaan Plaza Dinar Malang. Skripsi. Tidak diterbitkan. Malang: Fakultas Psikologi UIN Maulana Malik Ibrahim.

Santrock, J. (2002). Perkembangan masa hidup. (J. Damanik, \& A. Chusairi, Terj.) Jakarta: Erlangga.

Singh, R. \&Mahato, S.(2014). Copingstrategies adopted by the institutionalized and noninstitutionalized elderly in Kathmandu, Nepal: A comparative correlational study. International Journal of Research and Development of Health, 2 (1), 1118.

Windy, L. (2017). Lansia yang menghuni panti werdha (Studi kasus orang tua yang dititipkan di Panti Werdha Hargo Dedali Surabaya pada etnis Jawa). Skripsi. Tidak diterbitkan. Surabaya: Program Studi Sosiologi FISIP Universitas Airlangga. Diakses 1 Maret 2019, dari http://repository.unair.ac.id/68108/3/ Fis.S.05.17\%20.\%20Win. $1 \% 20-\% 20$ JURNAL.pdf.

Yuliana, Anna, Y., \& Roswiyani. (2018). Hubungan antara dukungan sosial dan coping dengan makna hidup remaja penyandang kanker. Jurnal Muara IImu Sosial, Humaniora, dan Seni, 2 (1), 262271. 